\title{
Trends In Coloured Nursing Education
}

\author{
A.M. Venter \\ Professor and Head of the Department of Nursing, \\ University of Western Cape.
}



\section{OPSOMMING}

Die opvoedkundige ont wikkeling van verpleging toon 'n interessante verloop. Die daarstelling van doeltreffende en voldoende fasiliteite vir opleiding van basiese verpleegstudente op diploma- en graadvlak sowel as na-basiese kursusse wat aangebied word deur gesondheidsinrigtings en aan universiteite, het 'n daadwerklike invloed op die motivering en belangstelling van verpleegsters gehad.

Dit het daartoe bygedra dat die getal geregistreerde Kleurling- en Indiërverpleegsters wat in 1959903 in getal was, gegroei het tot 3457 (slegs Kleurlinge) aan die einde van 1977.

Dit is noodsaaklik dat alle verpleegsters hulself steeds op hoogte hou van huidige tendense in die beroep ten einde in staat te wees om die toenemende eise wat deur die beroep aan hulle gestel word, die hoof te kan bied.

Hierdie ideaal kan slegs bereik word deur volgehoue studie, navorsing en indiensopleiding.

\section{INTRODUCTION}

$\mathbf{E}$ DUCATION as a selfgrowth process implies the potential successful adaptation to the world in which one lives; the latter becoming increasingly demanding through the expansion and growth of society as a whole.

The Coloured nursing student of today, like all other students, lives in a fantastic era of technological advancement. industrialization, a continual struggle for academic achievement and above all the drive to achieve adjustment within the changing framework of society. The student must therefore be prepared to learn - which is a mental activity by means of which knowledge, skills, attitudes, and ideals are acquired, resulting in the modification of behaviour.

The present-day nurse educator, therefore, not only has to be professionally and academically prepared for the educational task in nursing science but has to constantly update knowledge so as to keep abreast of the total interrelated picture of basic human science development. The success or failure of the student when she enters the professional world is an irrevocable reflection of the effectiveness of her teachers.
In nursing education we primarily set a standard of thoroughly motivated objectives whereby the student may be successfully introduced to health science as a collective and applied discipline. A farsighted, highly motivated and adaptable individual whose preparation goes beyond academic learning and professional skill, is needed to train the Coloured professional nurse of tomorrow

There is no difference between the educational programme followed for Coloured nursing students and that which is carried out for any other race group, but as in any other educational field the lecturer has to consider the social background e.g. religion, beliefs, morals and values of the target group involved. Careful investigation of the above could lead to knowledgeable insight into the biological and psychosocial needs of the particular community demanding the service of the professional nurse on completion of her training.

Although Coloured nursing education is reflecting a steadily increasing picture of growth on basic and post-basic diploma and degree levels of nursing education, yet advancement is still being complicated by certain relevant matters in respect of the existing situation. Factors worth 
mentioning are inter alia physical facilities such as the lack of living-in accommodation for Coloured nurses at some training hospitals, public transport which is noticeably inadequate pertaining to the duty hours demanded from the nurse and insufficient applicants in possession of an academic senior certificate. The noticeable shortcoming as regards the educational standard which is maintained in Coloured schools, specifically relates to the shortage of teachers in the tuition of the natural sciences, the latter being a strong recommendation in considering the pre-requisites for training in relation to the extent of the syllabus. Very few Coloured teachers in these specialized fields hold the appropriate qualifications for teaching natural sciences or mathematics.

Particular mention should be made however of the fact that the provision for the training of Coloured nurses has brought about a much larger number of available nurse professionals. This results in a far more adequate staff position in hospital wards and/or other related services as well as the maintenance of a high standard of patient care.

Since the beginning of 1978 most South African universities have been open to post-basic, post-graduate nursing students of all races. This factor is a very important one considering that some universitites do not have Medical Faculties. Registered Coloured nurses are therefore in a position to do courses at universities with Medical Faculties where special courses e.g. in Advanced Clinical Nursing are offered.

It has been experienced at the University of the Western Cape that the particularly strict and careful selection of pregraduate students is imperative as it has proved successful in raising the academic achievements and practical skills of the students. They are also very responsible, mature and wellbalanced on completion of the course. Total commitment of these students as regards hospital nursing and nurses' home matters is important and all student nurses are therefore exposed to a full orientation programme prior to commencement of lectures and practical skills.

The particular need to educate Coloured nurses on postbasic level must not be overlooked as within a Coloured population of 9,4 million (1970) which also reflects a particularly high population growth rate, the needs and demands of the community should be considered in their entirety.

Coloured nursing education should not only concern itself with the academic achievement and skilful practical task fulfilment, but should objectively aim at the improvement of the socio-economic status and uplifting of the Coloured population as a whole.
BASIC REGISTRATION FOR GENERAL NURSES

The first Coloured general nurse was E.R. Gow. She passed in December 1919 and was registered on 6 January 1920. On 18 June 1920 she was admitted to the register as a midwife, being the first Coloured person to be registered as a general nurse and midwife

Since then the increase in the number of Coloured nurses has been slow but steady. This slow rate was not only due to lack of recruits with the necessary educational qualifications but also due to the lack of facilities and employment opportunities for Coloured nurses. With the policy of separate development additional training facilities as well as opportunities were provided.

\section{GROWTH IN THE NUMBER OF COLOURED NURSES} AND MIDWIVES

Due to the similarity in the sumames of Coloured and White nurses, it is not possible to arrive at an accurate figure of Coloured registered nurses who had been admitted to the register of the various Councils prior to 1957

Prior to 1973 Indians were included under Coloured persons. The Nursing Amendment Act No. 50 of 1972 introduced separate registers and rolls for Indians. This involved the transfer of a number of persons from the register of Coloured persons to that of Indian persons.

Increases in respect of Coloured persons were comparatively high. This was due to the fact that the training of Coloured nurses developed rapidly during the past 1,5 decades.

Regulations prescribing standard 10 as an admission requirement were published on 28 November 1968 in respect of student general nurses and became compulsory on 28 November 1970. This resulted in a decline in the number of Coloured student nurses who commenced training in 1970 and 1971 .

Notwithstanding this fact there is a vast change in the picture as regards the number of Coloured registrations over the past 70 years. The registration figure for Coloureds and Indians rose from 0-903 during the period 1909-1959. The number of Coloured registered persons during the period 1969-1977 was as follows:

31 December 1969 (including Indian 2455

31 December 1974 (only Coloureds) 3107

31 December 1976 (on!y Coloureds) 3279

31 December 1977 (only Coloureds) 3457

Throughout the years there was also a steady rise in the number of training schools for student nurses.

TABLE I

Number of Nursing Schools which admitted Coloured and Indian Nurses and Student Midwives during the year ending 31 December.

\begin{tabular}{|c|c|c|c|c|c|}
\hline \multirow{2}{*}{ YEAR } & \multicolumn{5}{|c|}{ NUMBER OF NURSING SCHOOLS } \\
\cline { 2 - 6 } & $\begin{array}{c}\text { General Nurses } \\
\text { Female }\end{array}$ & $\begin{array}{c}\text { General Nurses } \\
\text { Male }\end{array}$ & $\begin{array}{c}\text { Mental Nurses } \\
\text { Female }\end{array}$ & $\begin{array}{c}\text { Mental Nurses } \\
\text { Male }\end{array}$ & Midwifery \\
\hline 1918 & - & - & - & - & 1 \\
1924 & 1 & - & - & - & 1 \\
1930 & 2 & - & - & - & 2 \\
1940 & 4 & - & - & 1 & 8 \\
1958 & 17 & 3 & - & - & 1 \\
\hline
\end{tabular}

Searle, C. - The History of the development of Nursing in South Africa - p. 307. 
TABLE II

Number of Recognized Training Schools for Non-White persons for 1969, 1974 and 1976.

\begin{tabular}{|l|r|r|r|}
\hline \multicolumn{1}{|c|}{ REGISTRATION } & 1969 & 1974 & 1976 \\
\hline Diploma in General Nursing & 52 & 75 & 71 \\
Diploma in Midwifery & 39 & 64 & 70 \\
Diploma in General Nursing and Midwifery & - & 7 & 24 \\
Diploma in Psychiatry & 5 & 7 & 8 \\
Diploma in General Nursing, Midwifery and Psychiatry & - & - & 8 \\
\hline
\end{tabular}

There is a comparatively high wastage of Coloured nursing students. As studies have shown, it is virtually impossible to ascertain exactly why this is so. A few possible reasons for this phenomenon could be:

1. Wrong choice of vocation which points to the need for effective vocational guidance at school.

2. Failure in passing as a result of inadequate academic preparation for nursing.

3. Competition of the private sector with nursing.

4. Lack of sufficient and efficient orientation with regard to nursing at some training schools once the student has assumed duty.

5. Personal reasons.

There has been dissatisfaction with the standard of general education of recruits to the nursing profession since 1944 when the Colonial Medical Council complained that the general standard of education of nursing recruits was not adequate for the demands which are made on them as professional persons with grave responsibilities.

Secondary education for girls had been very inadequately developed in the years before World War II, especially for Non-Whites. Compulsory lower education had already been fully instituted in 1923 for White people but not yet for Coloureds. Nursing examination results were adversely affected in the post war-period as selection procedures were virtually abandoned due to the great demand for nurses.

Nowadays the picture is changing rapidly as there is an increasing number of Coloured students in possession of a Senior or Matriculation Certificate applying to follow nursing courses. This could be due to the following reasons:

1. Rising unemployment figures.

2. Population explosion.

3. Security offered by nursing as a career.

4. Improved status of nurses.

5. Improved standard of living and educational facilities. A disturbing factor however, with respect to Coloured matriculants applying for nursing, is the lack of science subjects as background for nursing. On investigation, nursing officials were told that pupils make their own choice of subjects on enrolment at schools. On further investigation however, statistics at the University of the Western Cape, the biggest source for science teachers at Coloured schools, reveal an alarming shortage of teachers following the natural science courses. The total number of graduates with B.Sc . since the University opened in 1962 up to date (1978) amount to 208. Discussions with educationalists at the university made it clear that although pupils enroll for science subjects at schools, suitably qualified science teachers are sparsely distributed over Coloured schools in the Republic and at most schools are non-existent. The pupils are therefore forced to choose non-science subjects or should they choose science subjects, lectures are offered by teachers who are not adequately qualified to give pupils the necessary background This brings about poor academic material and a vicious circle develops.

\section{B. CURATIONIS}

This integrated course of 4,5-year duration commenced in 1972 when 11 students registered. Since then the total of students following the B. Cur. course has shown an increase; the present total being 34 for 1978 .

\section{TABLE III}

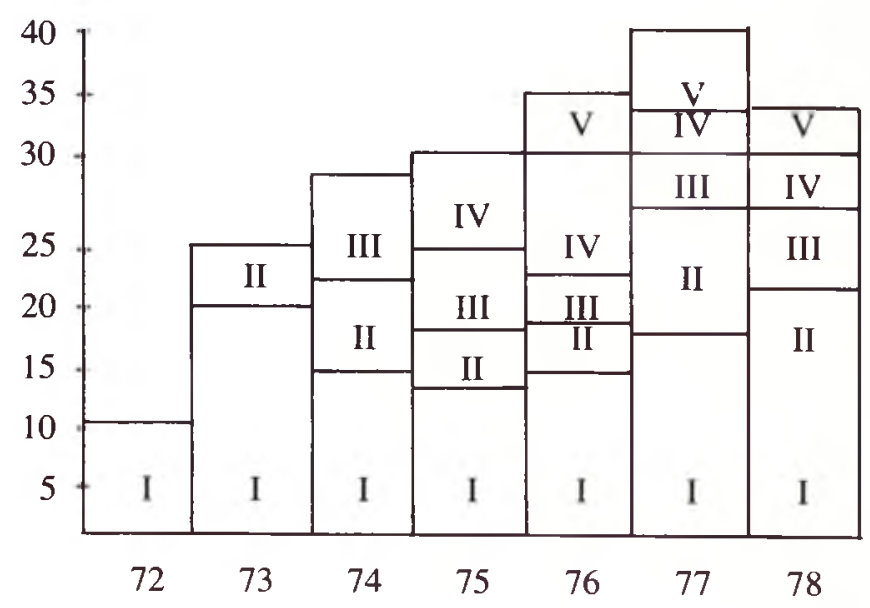

Two groups of students have already completed the course. This table will be discussed in more detail when the process of selection is dealt with.

\section{OBJECTIVES}

The objectives underlying the curriculum design of the course are not only oriented towards knowledge but are inclusive of goals such as preparation of nurses to fulfil a comprehensive task against the background of modern 
changing society. Constant attempts are being made to guide students towards skilful, responsible and intellectual development so as to ensure that they will react competently and with confidence in emergency situations. The role of the nurse in the community is particularly emphasized.

The subjects these students have to complete are believed to give them the necessary background and maturity to be capable and responsible ward sisters once they have completed the course.

They are required to do Nursing I, II, III, IV and V of which the last semester in the fourth year and the first semester in the fifth year are devoted to midwifery during which time they also do courses in cytology and family planning. They all have to follow Psychology I and Sociology I and are allowed to choose between one of these two subjects as their second major course.

Furthermore they are required to do Anatomy Special, Physiology Special, Applied Physics, Applied Chemistry, Microbiology and Preventive and Promotive Health. These subjects are offered to pre-graduate students and students following the Diploma in Nursing Education on a combined level. This would enable the graduates exemption for these subjects should they wish to follow post-basic courses e.g. Diploma in Nursing Education or the Diploma in Operating Theatre Technique

\section{PRACTICAL WORK}

The students are constantly motivated to regard the patient as the most important person in a hospital. They are therefore very enthusiastic about their practical work. During university holidays and during the fourth and fifth year they work for 40 hours per week (excluding 44 days annual leave). They often express their regret that it is not possible to spend longer hours doing practical work during their first 3 years when they only do 9,16 and 20 hours respectively.

The practical part of the course is offered at Tygerberg Hospital, a unique field for training as the hospital is extremely well equipped and presents the student nurse with a true picture of technological advancement, an academic climate for research etc.

The practical training is inclusive of lecture demonstrations, procedures, case studies and presentations and projects. The clinical department of the hospital undertakes to a large extent the practical nursing science but university lecturers are also involved. Lecturers spend sessions at the hospital to do bedside teaching while the student nurses are doing practical work in the wards. This is encouraging for the student and relates well to the correlation of theoretical and practical work and also leads to reinforcement of individualized learning skills and spot teaching.

During the fourth year the student is given the opportunity to become skilful in the more advanced technical skills such as suturing of wounds, blood-sampling, history-taking, making of a provisional diagnoses etc. Total patient-evaluation and skilful intervention of a therapeutic plan are given specific consideration.

\section{SELECTION}

Provisional selection is undertaken during October/November of the preceding year and is based on scholastic achievement.

On completion of the first semester, a second selection is done and the following points are considered:

- Marks obtained in all courses

- Practical performance

- Ward reports

- General attitude of student towards nursing.

This selection programme has ensured that only the best students have continued with the course throughout. The quality of the practical work of these students as well as their academic achievement is reflected in the final examination results obtained. The failure rate of students in the years following the selection has been relatively low.

\section{FIGURE I}

\section{Comparison between appointments and wastage during} the first year: 1972-1978

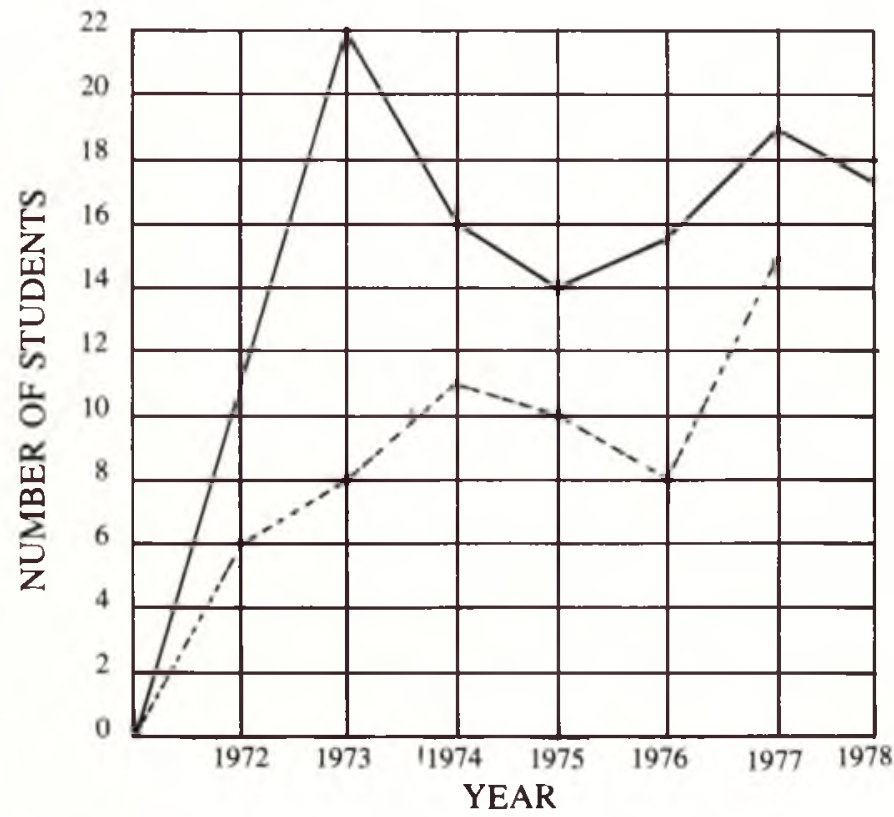

No. of first years

-...-Wastage

The main reason for the great decline in numbers from first year to second year is the fact that Anatomy Special is a pre-requisite for promotion to the second year and that the students are not allowed to repeat the first year. 
FIGURE II

Analysis of reasons for wastages 1972-1977 (First year students)

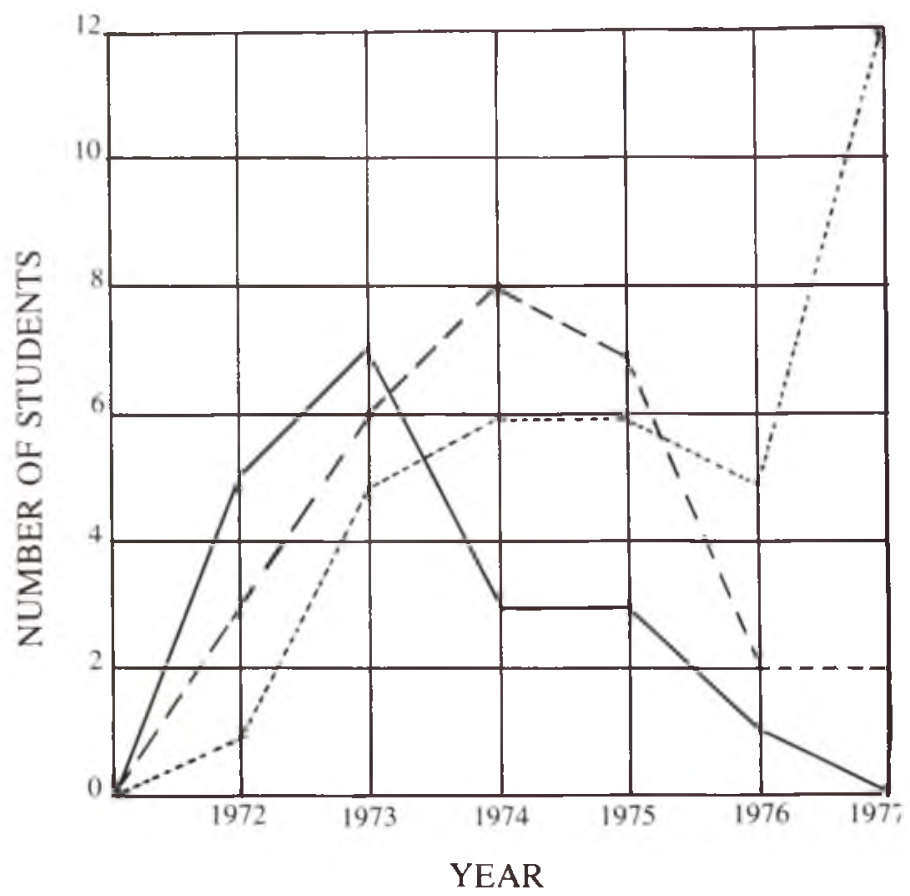

Not allowed to continue with training after first semester. Personal reasons. Not allowed to enter for examination or failed.
BASIC NURSING EDUCATION LEADING TO ENROLMENT

In 1948 the Cape Provincial Administration introduced training for Coloured auxiliary nurses. This was done to meet the shortage of registered nurses in hospitals.

\section{THE ROLE OF MIDWIFERY IN COLOURED NURSING EDUCATION}

St. Monica's Maternity Hospital was the first hospital in the Republic of South Africa to train Coloured midwives. The first course started in 1917. One of the three students who started their training, Mrs. Georgina A.P.D. Judson, wrote her final examination on 14 December 1917 and was registered on 8 January 1918 , being the first Coloured midwife in South Africa. The total number of midwives trained by St. Monica's Maternity Hospital totals 796 up to date.

Since 1917 the number of training schools for midwives steadily increased e.g. in 1969 there were 39 and in 1974 64 training schools, and a total of 197 coloured midwives were registered in 1977 .

These midwives render a valuable service to the Coloured community either as private practitioners or in employment of various Provincial district maternity services.

In the Cape Peninsula they have an active and valuable discussion group linked with the Westcol Branch of the South African Nursing Association.

\section{OBJECTIVES}

1. To regard midwifery as a fundamental in nursing education.

2. To establish a farsighted and comprehensive attitude to nursing practice.

3. To ensure that a high standard of family-centred care is maintained by professional nurses.

4. To equip the professional nurse adequately for her extended role.

5. To lay some foundation prior to post-graduate education.

\section{POST BASIC COURSES}

The 1,5-year Diploma Course in Nursing Education was instituted at the University of the Western Cape in 1966. This was the first nursing course to be introduced at this university and eight students completed this course in June 1967. By June 1976, a total of 63 students had obtained this qualification at this university.

In 1976 the duration of the course was extended to two years and the first seven students who registered for this longer course qualified at the end of 1977 . The main objectives of the Diploma Course in Nursing Education are, firstly, to train educators who will not only teach nurses but who will become directly involved and committed in the health education of the community as a whole.

Secondly the course is aimed at giving student tutors a wide and meaningful background at academic level so that 
they will be able to obtain exemption for certain courses should they be interested in doing a post-basic degree.

The course for the Diploma in Nursing Administration was first instituted at the Conradie Hospital Lecture Department and in 1968. when this Department closed down. it was offered at Tygerberg Hospital. In 1975 the course was instituted at the University of the Western Cape but due to the fact that there were too tew suitable applicants, it was held over till 1976 when four candidates registered for and completed the course.

During 1977 the same problem of too few candidates in possession of the required academic standard (Std. 10) was encountered and the course could not be offered.

At the beginning of this year five candidates were admitted to do the diploma course. The syllabus is compiled to give the students a background and knowledge to equip them adequately to fulfil the extremely demanding task of the chief nurse administrator. Matrons working in specialized administrative units of certain hospitals are requested to lecture on their specialities and subjects such as administration. public administration. nursing education administration. industrial psychology and the social sciences are emphasized.

When the 1.5-year Diploma Course in Operating Theatre Technique was first introduced in 1976 at the University of the Western Cape, it was the first time in history that a course in this branch of nursing had been introduced at university level

Five students registered $n$ 1976. At present there are 11 students following this course. It is required of the students to do Anatomy Special. Physiology Special, Applied Physics, Applied Chemistry and Microbiology with the Diploma in Nursing Education students. Should they desire to do the Nursing Education course at a later stage. they could apply for exemption for these courses. An intensive study is also made of surgery, anaesthetics, operating technique and departmental management.

This course was introduced at university level for various reasons - the most important being:

1. The need to prepare the theatre nurse at university level in order to enable her to meet the demands of the increasing standard of work and responsibility required of her.

2. To co-ordinate all the courses from the various hospitals in the Cape Province where one or two students were trained at a time and which proved to be uneconomic as all the lectures had to be repeated at each hospital.

3. To give the course a university status with the idea of stimulation of interest as there is always a serious shortage of trained operating theatre personnel.
In 1965 the Cape Technical College offered a course in Public Health at post-basic level on an extra-mural basis to trained coloured nurses. as no provisions had yet been made in this respect. The Peninsula Technical College for Higher Education commenced a course full-time in 1968. During the period 1968-1976. 120 qualified coloured nurses have obtained the Diploma in Community Health Nursing Science on this basis.

In order to meet the needs of the Coloured community presentation of Community Health Nursing Science as a subject in their nursing tuition should be a primary consideration.

The growth rate of the Coloured population has been estimated as the highest of all races in this country. thus giving rise to the particularly high incidence of physical disease and social pathology. The necessity to educate $\mathrm{Col}$ oured nurses in this subject on basic and post-basic courses has been evident for more than a decade: so as to guide professional Coloured nurses towards high quality community care with specific and continual focus on family planning. health education. role fulfilment in environmental health.

At the present time Coloured nurses have the opportunity to obtain this qualification not only at diploma level at hospitals or colleges but at diploma or degree level through the University of South Africa.

\section{CONCLUSION}

The remarkable motivation and drive of Coloured nurses to qualify academically has earned them the praise they deserve. It is therefore the obligation of all nurse-educators to uphold and constantly improve on the basic educational standards so as to equip as many Coloured professional nurses as adequately as possible to enable them to carry out the age-old health prerogative of man

\section{BIBLIOGRAPHY}

ANDERSON, C L Health Principles and Practice - Sixth Edition St. Louis: C V. Mosby Co, 1970

FREEMAN, R B Commumw Health Nursing Practice Philadelphia: W. B. Saunders Co., 1970

MALHER BE, E.C. Educanon in Sowh Africa. VI. I Cape Town; Juta and Co. Lid. 1975

PATON. F Aspekte van Verpleegonderwys seder 1974 S. A Verplegingstidskrif 1977. XLIV No. 3

SEARLE C The History of the Development of Nursing in South Africa Pretoria: SEARLE. C. The History of the

S.A Nursing Association 1966. SEARLF, C Aspekle van Gem
Verpleegstersvereniging. 197.3

S. A NURSING COUNCIL Repon of the Sirth Council Pretoria: Term of office S. A. NURSING COUNC
$1.4 .1970-31.4 .1975$

S. A VERPLEEGSTERS VERENIGING Beknople recks mo. +

UNIVERSITY OF THE WESTERN CAPE Statistics. Department of Development. 1977 